\title{
Vertical and Horizontal Distribution of Pollination Systems in Cerrado Fragments of Central Brazil
}

\author{
Fernanda Quintas Martins* and Marco Antônio Batalha \\ ${ }^{I}$ Departamento de Botânica; Universidade Federal de São Carlos; C.P. 676; fernanda_quintas@uol.com.br; \\ marcobat@uol.com.br; 13565-905; São Carlos - SP - Brasil
}

\begin{abstract}
In fragments of the cerrado, we determined the frequency of pollination systems and analyzed their spatial distribution. We placed 38 transects, sampling 2,280 individuals and 121 species. As expected in Neotropical regions, bee-pollination was the most frequent pollination system. We found a decrease in the frequency of plants pollinated by beetles towards the fragment interior. Similarly, we found significant variation in relation to height just for the bats; there was an increase in the frequency of plants pollinated by bats towards the higher heights. In general, we found no horizontal and vertical variation in the pollination systems, probably as consequence of the more open physiognomy of the cerrado vegetation.
\end{abstract}

Key words: Central-western Brazil, cerrado, pollination, savanna, spatial distribution, woody component

\section{INTRODUCTION}

Patterns of variation in plant-pollinator systems along environmental gradients have been addressed in a variety of ecological and spatial scales (Devoto et al., 2005). Different authors (e.g., Bawa, 1974; Kaur et al., 1978; Bawa, 1990) have attempted to use reproductive features to explain the general patterns of diversity and community structure found in the tropical woodlands with the underlying idea that the plant diversity and spatial distribution are dependent on reproductive processes (Heithaus, 1974). Studies on the reproductive biology of cerrado plant species have shown a great diversity of pollination systems, similar to those found in Neotropical forests (Oliveira and Gibbs, 2002). The data emerging from the reproductive biology of plants have important consequences for conservation and understanding of the organization of cerrado communities (Oliveira and Gibbs, 2002). Geographical and environmental distribution patterns of the different pollination systems have been identified, and the dominance of some groups may, to a certain extent, characterize different communities (Regal, 1982; Bawa, 1990).

The Cerrado Domain occupied originally $23 \%$ of the Brazilian territory (ca. 2 million $\mathrm{km}^{2}$ ), especially in the Central Plateau, being the second largest phytogeographic province of Brazil (Ratter et al., 1997). As its name implies, in the Cerrado Domain, the cerrado vegetation prevails. The cerrado vegetation is not uniform in physiognomy (Coutinho, 1990), ranging from grassland to tall woodland, but most of its physiognomies lie within the range defined as tropical savanna (Sarmiento, 1983). Castro et al. (1999) estimated that 3,000 to 7,000 vascular plant species occur in this vegetation type, from which 1,000 to 2,000 belong to the woody component.

\footnotetext{
${ }^{*}$ Author for correspondence
} 
As in other tropical communities (Bawa, 1990), plant-pollinator relationships in the cerrado seem to involve guilds of pollinators associated with a given plant or group of plants (Oliveira and Gibbs, 2000). There are few one-to-one plant-pollinator relationships, although many taxa are still poorly studied (Oliveira and Gibbs, 2002). Bee pollination is dominant both in cerrado and Neotropical forests (Oliveira and Gibbs, 2000; Dulmen, 2001; Ramírez, 2004). Many large-bee genera observed in cerrado were also reported for wet and dry forests in Costa Rica (Bawa et al., 1985; Kress and Beach, 1994), as well as the small Meliponinae and Halictidae bees. In the cerrado, bees are the main pollinators, but other pollinators visit flowers of both woody and herbaceous cerrado species (Oliveira and Gibbs, 2002). Rare and almost absent groups are butterflies and hummingbirds, which are frequent opportunist visitors or only secondary visitors of many woody species (Oliveira and Gibbs, 2000).

The relationships between plants and pollinators are very important to the structure and biological organization of communities, affecting spatial distribution, abundance, richness, trophic structure, and phenodynamic (Heithaus, 1974; Frankie, 1975; Bawa et al., 1985; Morellato, 1991), as well as genetic diversity by providing gene flow (Nason et al., 1997). The structure of the vegetation can also be related to its reproduction, since it interferes in the horizontal and vertical organization of the plants (Ramírez, 1993). Pollination system patterns can vary according to climate, altitude, geographic region, and vegetation type (Silberbauer-Gottsberger and Gottsberger, 1988). The main selective pressures on pollination strategies stem mainly from the environment in which the plants occur, such as subcanopy, canopy, edge, or interior of a given fragment (Opler et al., 1980a; Waller, 1988; Morellato, 1991). Thus, different environmental conditions between the edge and the interior of the fragments or between the lower and the upper strata - differences in humidity, illumination, and airflow - increase the differences between ecological niches (Roth, 1987) and may imply differences in the proportions of pollination systems (Smith, 1973).

Pollination systems are not randomly distributed in the community (Bawa et al., 1985). There are, for example, differences between the species reaching the canopy and those living in the inferior strata (Bawa et al., 1985). Since the vertical structure of the vegetation results in stratification of food resources and microclimate, the animal community may also be stratified (Smith, 1973). Thus, each vegetation stratum may have its own characteristic pollinators (Smith, 1973), which, in turn, may be related to vertical differences in flower morphology (Bawa and Opler, 1975; Opler et al., 1980a; Bawa et al., 1985). Vertical stratification of pollination systems may also occur in the cerrado (Oliveira and Gibbs, 2002). Moths and bats are pollinators mostly of trees, whereas wind and hummingbird pollination appear mostly in the herbaceous layer (Oliveira and Gibbs, 2002). Although Araújo (2001) found no significant difference in the distribution of the pollination systems between the border and the interior of woodland fragments in the Brazilian Pantanal, species pollinated by wind, bats, and hummingbirds were not found inside seasonal forest fragments (Opler et al., 1980b; Morellato, 1991).

Community level studies on different pollination systems may ultimately prove to be vital in understanding community structure and organization (Bawa et al., 1985). We determined the frequency of pollination systems in the woody component and analyzed the spatial distribution of these systems horizontally - in relation to distance from edge - and vertically - in relation to height in some cerrado fragments. We tried to answer the following questions: What are the frequencies of the pollination systems among cerrado woody species? Did these frequencies vary from the edge to the interior of the fragments? Did these frequencies vary in relation to height?

\section{MATERIAL AND METHODS}

We carried out this study in the municipalities of Alto Taquari (Mato Grosso state), Alcinópolis (Mato Grosso do Sul state), and Mineiros (Goiás state), central-western Brazil, in the southwestern portion of the Brazilian Central Plateau. Regional climate is classified as Aw (Köppen, 1931), that is, humid tropical with wet summer and dry winter. Annual rainfall varies from 1,200 to $2,000 \mathrm{~mm}$, concentrated from October to March, and mean annual temperature lies around $24.6^{\circ} \mathrm{C}$ (RamosNeto and Pivello, 2000). This region was originally covered mainly by cerrado vegetation, from open (campo limpo, a grassland savanna) to 
closed (cerradão, a tall woodland) physiognomies, following Coutinho's (1990) classification.

Based on satellite images, we randomly picked five fragments covered mainly by cerrado sensu stricto (a woodland): the first fragment (approximately, 22K0283659S and 8036276W UTM), with 8,278 ha; the second one (approximately, 22K0279934S and 8043454W UTM), with 1,678 ha; the third one (approximately, 22K0267453S and 8056613W UTM), with 41,452 ha; the fourth one (approximately, 22K0240604S and 8039048W UTM), with 6.666 ha; and the fifth (approximately, 22K0215774S and 7990493W UTM), with 12,459 ha. All fragments were located inside private properties and surrounded by agriculture and pasture.

On the satellite image, we randomly picked the initial points of transects. We placed 38 transects in the five fragments: eight in the first and fourth ones, four in the second one, twelve in the third one; and six in the fifth one. In a given fragment, the transects were at least $100 \mathrm{~m}$ apart each other. In each transect, we placed 15 sampling points 10 $\mathrm{m}$ apart each other, starting at $10 \mathrm{~m}$ from the fragment edge. We used the point-quarter method (Mueller-Dombois and Ellenberg, 1974) to sample the woody component. In each point, we sampled four woody plants with stem diameter at soil level equal to or larger than $3 \mathrm{~cm}$, all potentially reproductive adults. Thus, in the 38 transects, we placed 570 points and sampled 2,280 individuals. We collected the sampled individuals and identified them by comparison with lodged material at the São Paulo Botanical Institute or at the Federal University of São Carlos herbaria, by comparison with the Emas National Park reference collection (Batalha and Martins, 2002), or by using identification keys based on vegetative characters (Batalha and Mantovani, 1999).

We classified the species into families following Judd et al. (1999) and into pollination systems based on the literature (e.g., SilberbauerGottsberger and Gottsberger, 1988; Barbosa, 1997; Borges, 2000; Oliveira and Gibbs, 2000). Occasionally, when we could not find data for a given species, we classified its pollination system based on data of related species of the same genus or based on their floral traits. We recognized the following pollination systems: wind, beetles, moths, bees, small insects, hummingbirds, and bats. The 'small insects' class included a varied assemblage of relatively small insects, such as small bees, beetles, flies, wasps, and butterflies (Bawa et al., 1985). Then we calculated the frequency of each pollination system among the sampled individuals.

To test whether the frequencies of the pollination systems varied with distance from edge and with height, we used regression analyses (Zar, 1999). We used only those pollination systems with at least ten individuals. We grouped the sampled individuals according to their distance from edge; that is, for a given distance, we sampled 152 individuals (four individuals per point and 38 points for each distance) and calculated the frequencies of each pollination system in these 152 individuals. In relation to height, we arranged the individuals in decreasing order of height and divided them in eight classes with similar number of individuals (Table 1). We calculated median height and the frequency of each pollination system in each class. In the regression analyses, "distance from edge" or "height class" were the independent variables and "frequency of a given pollination system" was the dependent one.

\section{RESULTS}

We sampled 2,280 individuals, representing 121 species and 38 families (Table 2). Fabaceae (24 species) and Myrtaceae (18 species) were the richest families, and Davilla elliptica A. St-Hil (337 individuals) and Myrcia bella Triana (246 individuals) were the best represented species. Of the 121 species, one was pollinated mainly by wind $(0.83 \%)$, three by beetles $(2.48 \%), 15$ by moths ( $12.40 \%), 65$ by bees $(53.72 \%), 30$ by small insects $(24.79 \%)$, two by hummingbirds $(1.65 \%)$, and five by bats (4.13\%). Of the 2,280 individuals, two were pollinated mainly by wind $(0.09 \%)$; ten, by beetles $(0.44 \%)$; 204 , by moths $(8.95 \%) ; 1,712$, by bees $(75.09 \%)$; 310 , by small insects $(13.59 \%)$; three, by hummingbirds $(0.13 \%)$; and 39 , by bats $(1.71 \%)$.

For four out of the five pollination systems with at least ten individuals, we found no significant variation in relation to distance from edge (moths: $R^{2}=0.006, P=0.604$; bees: $R^{2}=0.007, P=0.733$; small insects: $R^{2}=0.007, P=0.790$; bats: $R^{2}=$ $0.083, P=0.227$; Fig. 1 ). We found a decrease in the frequency of plants pollinated by beetles towards the fragment interior $\left(R^{2}=0.210, P=\right.$ 0.034; Fig. 1). Similarly, for four out of the five 
pollination systems with at least ten individuals, we found no significant variation in relation to height (moths: $R^{2}=0.351, P=0.155$; beetles: $R^{2}=$ $0.324, P=0.247$; bees: $R^{2}=0.391, P=0.075$; small insects: $R^{2}=0.445, P=0.067$; Fig. 2). We found an increase in the frequency of plants pollinated by bats towards higher heights $\left(R^{2}=\right.$ 0.632, $P=0.005 ;$ Fig. 2).

$\underline{\text { Table } 1 \text { - Height classes with number of individuals in five cerrado fragments of central Brazil. }}$

\begin{tabular}{cc}
\hline height $(\mathbf{m})$ & individuals \\
\hline lower limit - upper limit & 294 \\
\hline $0.16-1.20$ & 278 \\
$1.20-1.55$ & 273 \\
$1.55-1.78$ & 250 \\
$1.78-1.90$ & 335 \\
$1.90-2.30$ & 280 \\
$2.30-2.85$ & 287 \\
$2.85-3.80$ & 283 \\
\hline
\end{tabular}

Table 2 - Pollination systems of the woody species sampled in five cerrado fragments, central Brazil. Family names were abbreviated according to Weber (1982). Pol - pollination systems; ba - bats; be - bees; bt - beetles; hb hummingbird; mo - moths; si - small insects; wi - wind. Sources: 1 - Araújo (2001), 2 - Barbosa (1997), 3 - Barros (1992), 4 - Barros (1998), 5 - Barros (2001), 6 - Bawa et al. (1985), 7 - Borges (2000), 8 - Franco (1995), 9 - Freitas and Oliveira (2002), 10 - Gibbs et al. (1999), 11 - Goldenberg and Shepherd (1998), 12 - Gottsberger (1986), 13 Gottsberger (1994), 14 - Gottsberger (1999), 15 - Oliveira and Gibbs (1994), 16 - Oliveira and Gibbs (2000), 17 Oliveira and Paula (2001), 18 - Oliveira and Sazima (1990), 19 - Oliveira et al. (1992), 20 - Oliveira et al. (2004), 21 - Proença and Gibbs (1994), 22 - Ramirez 2004, 23 - Saraiva et al. (1988), 24 - Sazima and Sazima (1975), 25 Sigrist (2001), 26 - Silberbauer-Gottsberger et al. (2003), 27 - Silberbauer-Gottsberger and Gottsberger (1988), 28 Torezan-Silingardi and Del-Claro (1998), 29 - Viana et al. (1997); * classification of the pollination systems based on the genus; + based in floral traits.

\begin{tabular}{|c|c|c|c|}
\hline Family & Species & Pol & Source \\
\hline Anacardiaceae & Anacardium humile A. St-Hil. & si & $2^{+}$ \\
\hline Anacardiaceae & Tapirira guianensis Aubl. & si & 17 \\
\hline Annonaceae & Annona coriacea Mart. & bt & 12,13 \\
\hline Annonaceae & Annona crassiflora Mart. & bt & 13,16 \\
\hline Annonaceae & Bocageopsis mattogrossensis (R.E. Fries) R.E. Fries & si & $15^{*}, 28^{*}$ \\
\hline Annonaceae & Duguetia furfuracea (A. St-Hil.) Benth. and Hook.f. & bt & 2,13 \\
\hline Apiaceae & Didymopanax macrocarpum (Cham. and Schltdl.) Seem. & si & $16,17^{*}$ \\
\hline Apiaceae & Didymopanax vinosum (Cham. and Schltdl.) Marchal & si & $16^{*}, 17^{*}$ \\
\hline Apocynaceae & Aspidosperma macrocarpon Mart. & mo & 16,20 \\
\hline Apocynaceae & Aspidosperma nobile Müll. Arg. & mo & $16^{*}, 17^{*}$ \\
\hline Apocynaceae & Aspidosperma polyneuron Müll. Arg. & mo & $16^{*}, 20^{*}$ \\
\hline Apocynaceae & Aspidosperma tomentosum Mart. & mo & 16,20 \\
\hline Apocynaceae & Hancornia speciosa Gomez & mo & $16^{*}, 20$ \\
\hline Apocynaceae & Himatanthus obovatus (Müll. Arg.) Woods. & mo & 7,20 \\
\hline Asteraceae & Eremanthus erythropappus Sch. Bip. & si & $2^{*}, 16^{*}$ \\
\hline Asteraceae & Eremanthus glomerulatus Less. & si & 16 \\
\hline Asteraceae & Piptocarpha rotundifolia (Less.) Baker & si & 16,17 \\
\hline Bignoniaceae & Tabebuia aurea (Silva Manso) S. Moore & be & 5,7 \\
\hline Bignoniaceae & Tabebuia ochracea (Cham.) Standl. & be & 5,16 \\
\hline Bignoniaceae & Zeyheria montana Mart. & $\mathrm{hb}$ & 2 \\
\hline Caryocaraceae & Caryocar brasiliense Cambess. & ba & 7,20 \\
\hline Celastraceae & Austroplenkia populnea (Reissek) Lund & si & 17 \\
\hline Celastraceae & Peritassa campestris (Cambess.) A.C. Sm. & be & $2^{+}$ \\
\hline Chrysobalanaceae & Couepia grandiflora (Mart. and Zucc.) Benth. ex Hook.f. & mo & 17,27 \\
\hline
\end{tabular}


(Cont. Table 1)

\begin{tabular}{|c|c|c|c|}
\hline Family & Species & Pol & Source \\
\hline Chrysobalanaceae & Licania humilis Cham. and Schltdl. & be & $1^{*}, 22^{*}$ \\
\hline Clusiaceae & Kielmeyera coriacea Mart. & be & 17,18 \\
\hline Clusiaceae & Kielmeyera rubriflora Cambess. & be & 18 \\
\hline Combretaceae & Buchenavia tomentosa Eichl. & si & + \\
\hline Connaraceae & Connarus suberosus Planch. & si & 7,16 \\
\hline Connaraceae & Rourea induta Planch. & be & 2 \\
\hline Dilleniaceae & Davilla elliptica A. St-Hil. & be & 2,7 \\
\hline Ebenaceae & Diospyros hispida A. DC. & mo & 20,27 \\
\hline Erythroxylaceae & Erythroxylum campestre A. St-Hil. & si & 2,4 \\
\hline Erythroxylaceae & Erythroxylum suberosum A. St-Hil. & si & 4,7 \\
\hline Erythroxylaceae & Erythroxylum tortuosum Mart. & si & 4,16 \\
\hline Euphorbiaceae & Manihot caerulescens Pohl & be & $1^{*}$ \\
\hline Euphorbiaceae & Maprounea guianensis Aubl. & si & 17 \\
\hline Euphorbiaceae & Pera glabrata (Schott.) Baill. & si & 17 \\
\hline Fabaceae & Acosmium subelegans (Mohl.) Yakovlev & be & 7 \\
\hline Fabaceae & Anadenanthera falcata (Benth.) Speg & si & $17^{*}$ \\
\hline Fabaceae & Andira anthelmia (Vell.) J.F. Macbr. & be & $7^{*}$ \\
\hline Fabaceae & Andira cuiabensis Benth. & be & 7 \\
\hline Fabaceae & Andira laurifolia Benth. & be & $7^{*}$ \\
\hline Fabaceae & Andira vermifuga (Mart.) Benth. & be & $7^{*}$ \\
\hline Fabaceae & Bauhinia rufa Steud. & ba & 10,17 \\
\hline Fabaceae & Bowdichia virgilioides Kunth & be & 7,17 \\
\hline Fabaceae & Copaifera langsdorffii Desf. & be & 9,17 \\
\hline Fabaceae & Dalbergia cuiabensis Benth. & be & $16^{*}, 17^{*}$ \\
\hline Fabaceae & Dalbergia miscolobium Benth. & be & 16,17 \\
\hline Fabaceae & Dimorphandra mollis Benth. & si & 7,16 \\
\hline Fabaceae & Dioclea bicolor Benth. & be & $8^{*}$ \\
\hline Fabaceae & Diptychandra aurantiaca Tul. & be & + \\
\hline Fabaceae & Harpalyce brasiliana Benth. & be & + \\
\hline Fabaceae & Hymenaea stigonocarpa Mart. & ba & 7,10 \\
\hline Fabaceae & Machaerium acutifolium Vogel & be & $7^{*}, 22^{*}$ \\
\hline Fabaceae & Plathymenia reticulata Benth. & si & + \\
\hline Fabaceae & Pterodon pubescens Benth. & be & $16^{*}$ \\
\hline Fabaceae & Sclerolobium aureum (Tul.) Benth. & si & 7 \\
\hline Fabaceae & Sclerolobium paniculatum Vogel & si & 16,17 \\
\hline Fabaceae & Senna silvestris (Vell.) H.S. Irwin and Barneby & be & 17,29 \\
\hline Fabaceae & Stryphnodrendon obovatum Benth. & si & $7,16^{*}$ \\
\hline Fabaceae & Vatairea macrocarpa (Benth.) Ducke & be & + \\
\hline Flacourtiaceae & Casearia sylvestris $\mathrm{Sw}$. & si & 2,7 \\
\hline Icacinaceae & Emmotum nitens (Benth.) Miers & si & 16,17 \\
\hline Lauraceae & Ocotea corymbosa (Meissn.) Mez. & si & 17 \\
\hline Lecythidaceae & Eschweilera nana (O.Berg) Miers & be & $6^{*}$ \\
\hline Loganiaceae & Strychnos pseudoquina A. St-Hil. & mo & 16,20 \\
\hline Lythraceae & Lafoensia pacari A. St-Hil. & ba & 7,24 \\
\hline Malpighiaceae & Banisteriopsis stellaris (Griseb.) B.Gates & be & $2^{*}, 12$ \\
\hline Malpighiaceae & Byrsonima basiloba A. Juss. & be & $2,3^{*}$ \\
\hline Malpighiaceae & Byrsonima coccolobifolia A. Juss. & be & 3,7 \\
\hline Malpighiaceae & Byrsonima crassa Nied. & be & 3,17 \\
\hline Malpighiaceae & Byrsonima intermedia A. Juss. & be & 2,12 \\
\hline Malpighiaceae & Peixotoa reticulata Griseb. & be & $2,25^{*}$ \\
\hline Malvaceae & Eriotheca gracilipes (K. Schum.) A. Robyns & be & 17,19 \\
\hline Malvaceae & Pseudobombax longiflorum (Mart. and Zucc.) A. Robyns & mo & 7,20 \\
\hline Melastomataceae & Miconia albicans Triana & be & 11,17 \\
\hline
\end{tabular}


(Cont. Table 1)

\begin{tabular}{|c|c|c|c|}
\hline Family & Species & Pol & Source \\
\hline Melastomataceae & Miconia fallax A. DC. & be & 11,16 \\
\hline Melastomataceae & Miconia ferruginata A. DC & be & $11^{*}$ \\
\hline Melastomataceae & Miconia ligustroides (A. DC.) Naud. & be & 11 \\
\hline Melastomataceae & Mouriri elliptica Mart. & be & $11^{*}$ \\
\hline Moraceae & Brosimum gaudichaudii Trec. & wi & 2,7 \\
\hline Myristicaceae & Virola sebifera Aubl. & si & 17 \\
\hline Myrtaceae & Campomanesia adamantium (Cambess.) O. Berg & be & $2^{*}, 28^{*}$ \\
\hline Myrtaceae & Campomanesia pubescens (A. DC.) O. Berg & be & 2,28 \\
\hline Myrtaceae & Eugenia aurata $\mathrm{O}$. Berg & be & 2,7 \\
\hline Myrtaceae & Eugenia bimarginata A. DC. & be & $2^{*}, 7^{*}$ \\
\hline Myrtaceae & Eugenia piauhiensis O. Berg & be & $2^{*}, 7^{*}$ \\
\hline Myrtaceae & Eugenia punicifolia (Kunth) A. DC. & be & 2 \\
\hline Myrtaceae & Myrcia bella Cambess. & be & $7^{*}, 21^{*}$ \\
\hline Myrtaceae & Myrcia camapuanensis N.F.E. Silveira & be & $7^{*}, 21^{*}$ \\
\hline Myrtaceae & Myrcia crassifolia (O. Berg) Kiaersk. & be & $7^{*}, 21$ \\
\hline Myrtaceae & Myrcia fallax (Rich.) A. DC. & be & $7^{*}, 21^{*}$ \\
\hline Myrtaceae & Myrcia guianensis A. DC. & be & $7^{*}, 21^{*}$ \\
\hline Myrtaceae & Myrcia laruotteana Cambess. & be & $7^{*}, 21^{*}$ \\
\hline Myrtaceae & Myrcia linguaeformis Kiaersk. & be & $7^{*}, 21^{*}$ \\
\hline Myrtaceae & Myrcia rhodeosepala Kiaersk. & be & 21 \\
\hline Myrtaceae & Myrcia sp. Nov. & be & $7^{*}, 21^{*}$ \\
\hline Myrtaceae & Myrcia torta A. DC. & be & $7^{*}, 21^{*}$ \\
\hline Myrtaceae & Myrcia uberavensis O. Berg & be & 2 \\
\hline Myrtaceae & Psidium laruotteanum Cambess. & be & $7^{*}, 21^{*}$ \\
\hline Nyctaginaceae & Guapira noxia (Netto) Lundell & si & 16,17 \\
\hline Nyctaginaceae & Neea theifera Oerst. & si & 7,16 \\
\hline Ochnaceae & Ouratea acuminata (A. DC.) Engl. & be & $2^{*}, 7^{*}$ \\
\hline Ochnaceae & Ouratea castaneaefolia (A. DC.) Engl. & be & 7,17 \\
\hline Ochnaceae & Ouratea semiserrata (Mart. and Nees) Engl. & be & $7,16^{*}$ \\
\hline Ochnaceae & Ouratea spectabilis (Mart.) Engl. & be & $2^{*}, 7^{*}$ \\
\hline Proteaceae & Roupala montana Aubl. & mo & 7,20 \\
\hline Rubiaceae & Chomelia ribesioides Benth.ex A. Gray & mo & $7^{*}$ \\
\hline Rubiaceae & Genipa americana $\mathrm{L}$. & be & 6 \\
\hline Rubiaceae & Palicourea rigida Kunth & hb & 2,16 \\
\hline Rubiaceae & Tocoyena formosa (Cham. and Schltdl.) K. Schum. & mo & 7,16 \\
\hline Sapindaceae & Toulicia tomentosa Radlk. & si & + \\
\hline Sapotaceae & Pouteria ramiflora (Mart.) Radlk. & mo & 27 \\
\hline Sapotaceae & Pouteria torta (Mart.) Radlk. & mo & 27 \\
\hline Simaroubaceae & Simarouba amara Aubl. & si & 6,17 \\
\hline Styracaceae & Styrax ferrugineum Nees and Mart. & be & 16,23 \\
\hline Vochysiaceae & Qualea grandiflora Mart. & mo & 7,20 \\
\hline Vochysiaceae & Qualea multiflora Mart. & be & 7,16 \\
\hline Vochysiaceae & Qualea parviflora Mart. & be & 7,16 \\
\hline Vochysiaceae & Vochysia thyrsoidea Pohl & be & 15,16 \\
\hline
\end{tabular}

\section{DISCUSSION}

Most woody species in the cerrado fragments we sampled were pollinated mainly by bees, followed by small insects and moths. Bees were the main pollinators in other cerrado sites as well, such as in Botucatu, southeastern Brazil (SilberbauerGottsberger and Gottsberger, 1988), and Brasilia, central Brazil (Oliveira and Gibbs, 2000), and in other vegetation types, such as rain forest (e.g., Bawa et al., 1985). Pollination by bees is the most frequent pollination system not only in the cerrado, but also in the Neotropical flora as a whole (Gentry, 1982). Most plants with rather conspicuous, often large, tubular flowers pollinated by specialized large and medium-sized 
bees belong to Amazonian-centered families, which are also the most frequent families in the cerrado flora, as, for example, Apocynaceae,

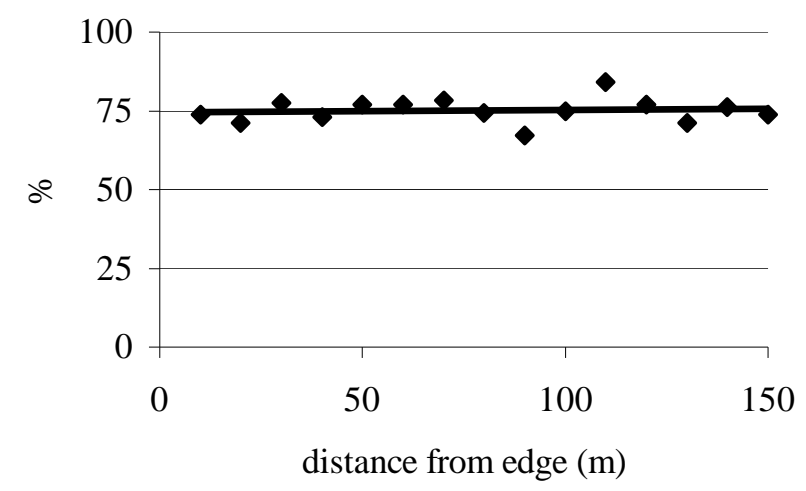

a

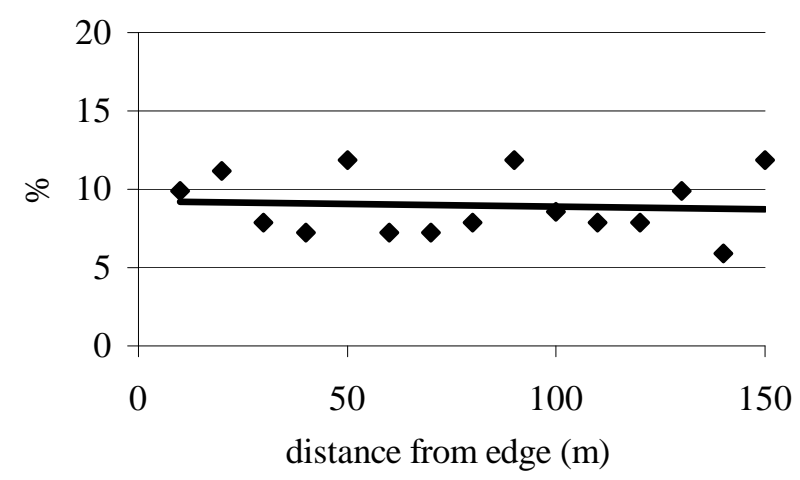

$\mathrm{c}$
Bignoniaceae, Lecythidaceae, and many Fabaceae (Gentry, 1982).

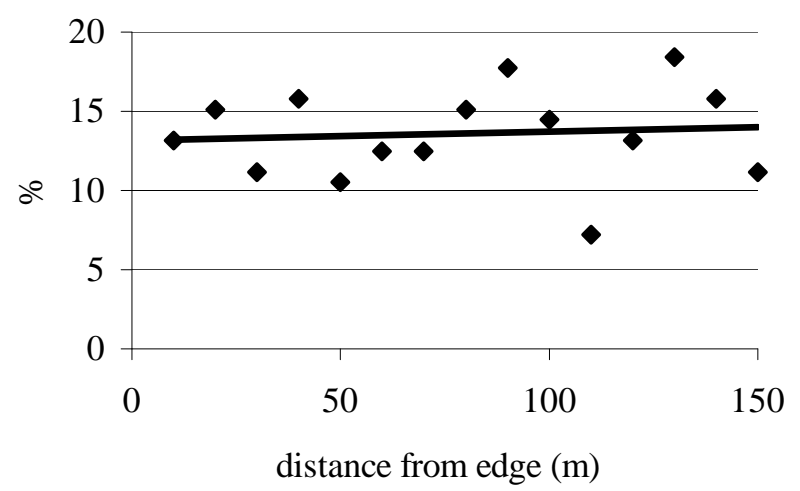

b

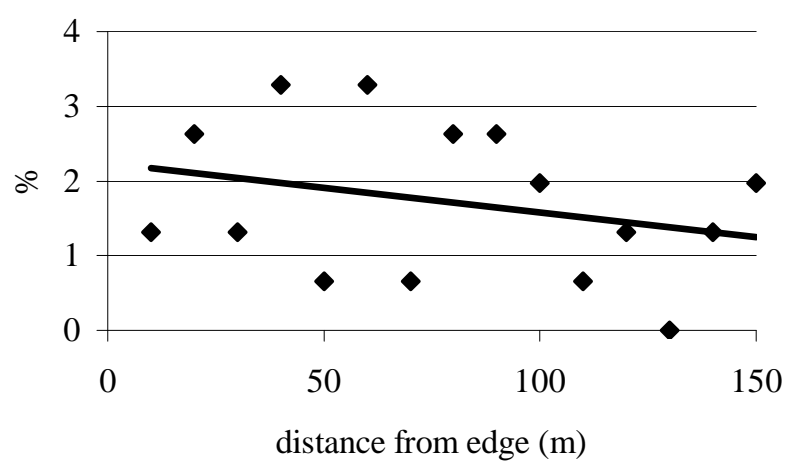

d

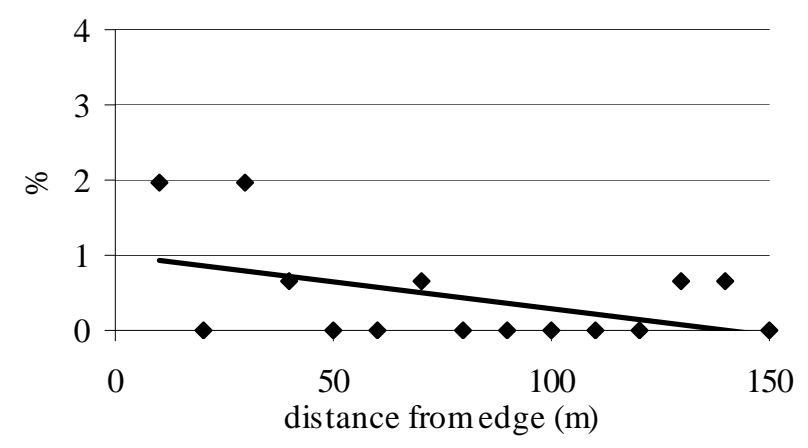

$\mathrm{e}$

Figure 1 - Regression analysis of the distance from edge in cerrado fragments of central Brazil: a bees $\left(R^{2}=0.007, P=0.733, a=0.008, b=74.486\right), \mathrm{b}-$ small insect $\left(R^{2}=0.007, P=\right.$ $0.790, a=0.005, b=13.164), \mathrm{c}-$ moth $\left(R^{2}=0.006, P=0.604, a=-0.004, b=9.229\right), \mathrm{d}$ - bats $\left(R^{2}=0.083, P=0.227, a=-0.007, b=2 ., 237\right)$, and e - beetles $\left(R^{2}=0.210, P=\right.$ $0.034, a=-0.007, b=1.002)$. 


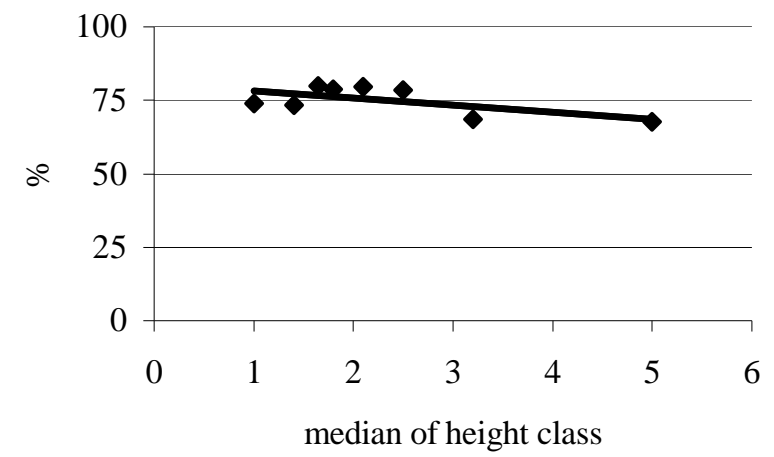

a

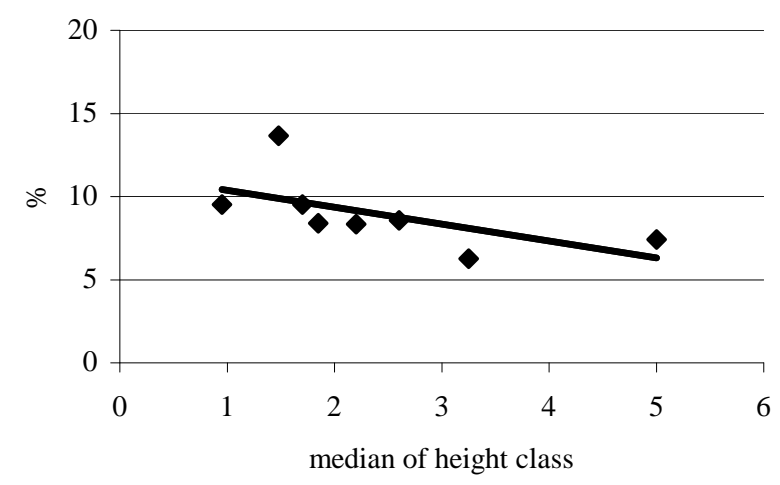

c

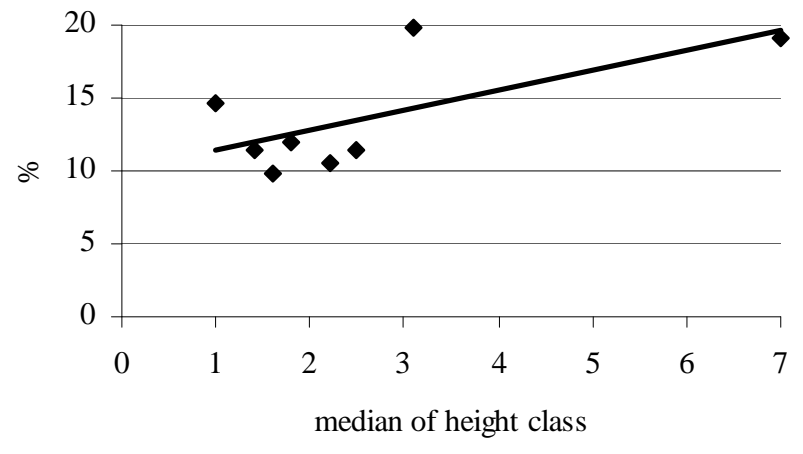

b

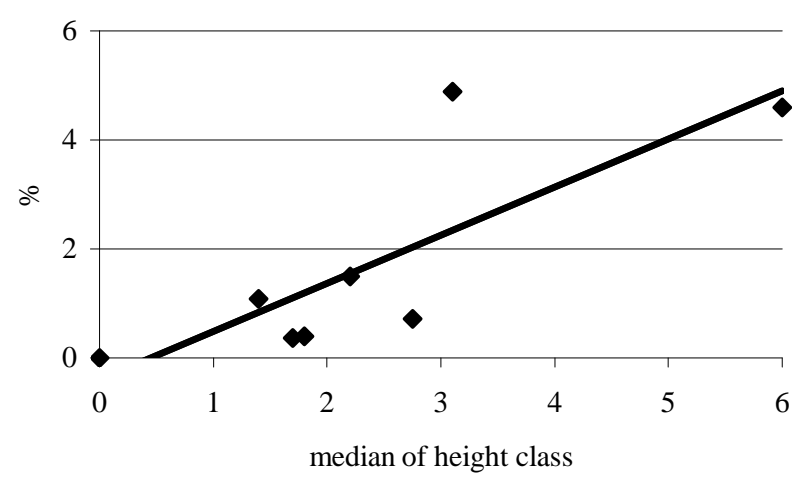

d

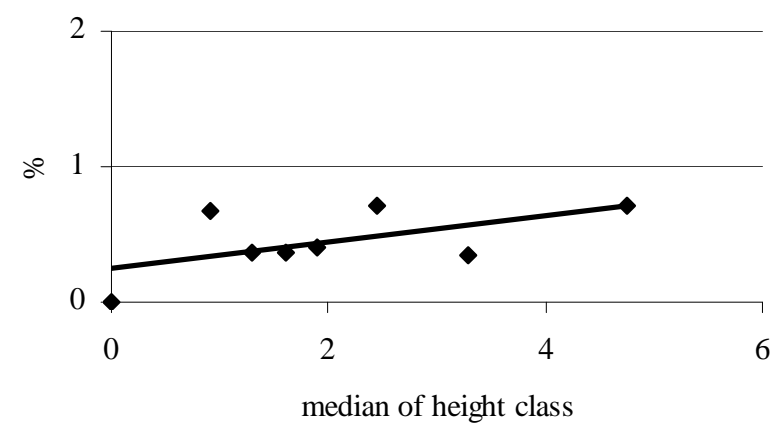

e

Figure 2 - Regression analysis of the height of woody species in cerrado fragments of central Brazil: a - bees $\left(R^{2}=0.391, P=0.075, a=-2.410, b=80.693\right), \mathrm{b}-$ small insect $\left(R^{2}=\right.$ $0.445, P=0.067, a=1.361, b=10.102), \mathrm{c}-\operatorname{moth}\left(R^{2}=0.351, P=0.155, a=-1.016, b\right.$ $=11 ., 384), \mathrm{d}-$ bats $\left(R^{2}=0.632, P=0.005, a=0.884, b=-0.403\right)$, and e - beetles $\left(R^{2}\right.$ $=0.324, P=0.247, a=0.094, b=0.256)$.

Corroborating Oliveira and Gibbs (2000), who stated that butterflies and hummingbirds are rare groups as main pollinators of cerrado woody species, we found no species pollinated mainly by 
butterflies and only two pollinated mainly by hummingbirds. Silberbauer-Gottsberger and Gottsberger (1988) postulated that some environmental conditions, especially high temperatures and low air humidity, would explain the low incidence of hummingbird pollination in cerrado sites.

Pollinating birds seem to be more abundant in habitats with a less seasonal climate, dominated by favorable conditions, which is associated with more constant and abundant food resources throughout the year (Ramírez, 2004). Though not frequent in cerrado woody species, butterfly and wind pollination may be important, respectively, among Asteraceae (Silberbauer-Gottsberger and Gottsberger, 1988) and grasses and sedges (Barbosa, 1997; Oliveira and Gibbs, 2000), families that are frequent among cerrado herbaceous species (Batalha and Martins, 2002).

Morellato (1991) found higher frequencies of bat-, bird-, and wind-pollinated species in the edge of rain forest fragments and of bee-pollinated species in the interior. Whereas the frequency of pollination systems varied from the edge to the interior in rain forest fragments (Morellato, 1991; Opler et al., 1980b), we did not find such trend for the pollination systems in cerrado fragments, except for the plants pollinated mainly by beetles, whose frequency decreased towards the fragment interior. The non-variation of most pollination system in cerrado fragments in relation to the distance from edge could be a consequence of the open physiognomy of the sampled vegetation. Since the cerrado sensu stricto physiognomy fits the definition of a tropical savanna (Bourlière and Hadley, 1983), the differences in environmental conditions between edge and core regions of these fragments may be not as high as those in forest fragments.

Species pollinated mainly by hummingbirds, small insects, beetles, butterflies, and moths should be particularly common in the subcanopy, whereas species pollinated mainly by medium-sized to large bees should be predominant in the canopy (Bawa et al., 1985; Ramirez, 1993). In forests, pollination systems present maximum diversity in the subcanopy, and although almost all systems occur in the canopy, approximately two thirds of the species in this stratum are pollinated by medium-sized to large bees and small diverse insects (Appanah, 1981; Bawa et al., 1985; Ramírez, 1989; Ramalho, 2004; Ramírez, 2004). Hummingbird and moth pollination systems are almost completely absent in the canopy trees (Appanah, 1981; Bawa et al., 1985; Ramirez, 1989).

Notwithstanding, we found no significant variation of the pollination system frequencies in relation to height, except for those plants pollinated by bats, whose frequency increased towards higher heights. The relative proportion of various pollination systems seems to be related to vegetation structure and floristic composition (Ramírez, 1989), and, in tropical communities, most pollinators act in a wide vertical space and only a few of them can be considered as exclusive of a determined strata (Ramírez, 1993). In a savanna, such as the cerrado sensu stricto we sampled, trees are much lower than in a forest, and, thus, restriction of pollinators to a determined strata should be much less frequent than in forests.

In this study, bees were the main pollinators; as expected in a Neotropical flora (Gentry, 1982). In general, we found no horizontal and vertical variation in the pollination systems, contrarily to what was found in forests. Probably, this was a consequence of the more open physiognomy of the cerrado fragments. There have been few studies that evaluated the distribution of pollination systems in relation to distance from the edge in fragments and tree height (Ramirez, 1993). Detailed studies on the ecological and geographical variations of the pollination systems in cerrado fragments are still lacking, especially concerning the herbaceous component and throughout the cerrado physiognomic gradient.

\section{ACKNOWLEDGMENTS}

We are grateful to Conservation International, especially Drs. Mário Barroso Ramos-Neto and Paulo Gustavo do Prado Pereira, and CNPq, for financial support; to Emas and Oréades Foundations, for satellite images; and to André Vitor Fleuri Jardim and Júlia Caram, for help in field.

\section{RESUMO}

As principais pressões seletivas nas estratégias de polinização originam principalmente do ambiente em que plantas ocorrem, como subdossel, dossel, borda ou interior de um fragmento. Diferentes 
condições ambientais aumentam as diferenças entre os nichos ecológicos e podem implicar diferenças nas proporções dos sistemas de polinização. Em fragmentos de cerrado, determinamos a freqüência dos sistemas de polinização e analisamos sua distribuição espacial. Lançamos 38 transecções aleatoriamente, amostrando 2.280 indivíduos e 121 espécies. Como esperado para regiões neotropicais, a polinização por abelhas foi o sistema de polinização mais freqüente. Encontramos uma diminuição na frequiência de plantas polinizadas por besouros em direção ao interior do fragmento. De modo similar, encontramos uma variação significativa em relação à altura somente para os morcegos, havendo um aumento na frequiência de plantas em direção a alturas mais altas. Em geral, não encontramos variações horizontais e verticais nos sistemas de polinização, provavelmente, como conseqüência da fisionomia mais aberta de cerrado.

\section{REFERENCES}

Appanah, S. (1981), Pollination in Malaysian primary forest. Malay. Forester, 44, 37-42.

Araújo, A. C. (2001), Flora, fenologia de floração e polinização em capões do Pantanal Sul Mato Grossense. PhD Thesis, State University of Campinas, Campinas, Brazil.

Barbosa, A. A. (1997), Biologia reprodutiva de uma comunidade de campo sujo, Uberlândia - MG. PhD Thesis, State University of Campinas, Campinas, Brazil.

Barros, M. G. (1992), Fenologia da floração, estratégias reprodutivas e polinização de espécies simpátricas do gênero Byrsonima Rich (Malpighiaceae). Rev. Brasil. Biol., 52, 343-353.

Barros, M. G. (1998), Sistemas reprodutivos e polinização em espécies simpátricas de Erythroxylum P.Br. (Erythroxylaceae) do Brasil. Rev. Brasil. Bot., 21, 159-166.

Barros, M. G. (2001), Pollination ecology of Tabebuia aurea (Manso) Benth. and Hook. and T. ochracea (Cham.) Standl. (Bignoniaceae) in Central Brazil cerrado vegetation. Rev. Brasil. Bot., 24, 255-261.

Batalha, M. A. and Mantovani, W. (1999), Chaves de identificação das espécies vegetais vasculares baseadas em caracteres vegetativos para a ARIE Cerrado Pé-de-Gigante (Santa Rita do Passa Quatro, SP). Rev. Inst. Flor., 11, 137-158.

Batalha, M. A. and Martins F. R. (2002), The vascular flora of the cerrado in Emas National Park (Goiás, central Brazil). Sida, 20, 295-312.
Bawa, K. S. (1974), Breeding system of tree species of lowland tropical community. Evolution, 28, 85-92.

Bawa, K. S. (1990), Plant-pollinator interactions in tropical rain forests. Ann. Rev. Ecol. Syst., 21, 399422.

Bawa, K. S. and Opler, P. A. (1975), Dioecism in tropical forest trees. Evolution, 29, 167-179.

Bawa, K. S.; Bulloch, S. H.; Perry, D. R.; Coville, R. E. and Grayum, M. H. (1985), Reproduction biology of tropical lowland rain forest tree. II. Pollination system. Am. J. Bot., 72, 346-356.

Borges, H. B. N. (2000), Biologia reprodutiva e conservação do estrato lenhoso numa comunidade do cerrado. PhD Thesis, State University of Campinas, Campinas, Brazil.

Bourlière, F. and Hadley, M. (1983), Present-day savannas: an overview. In - Ecosystems of the world tropical savannas, ed. D. W. Goodall. Elsevier, Amsterdam, pp. 1-17.

Castro, A. A. J. F.; Martins, F. R.; Tamashiro, J. Y. and Shepherd, G. J. (1999), How rich is the flora of the Brazilian cerrados? Ann. Miss. Bot. Gard., 86, 192224.

Coutinho, L. M. (1990), Fire in the ecology of the Brazilian cerrado. In - Fire in the tropical biota, ed. J. G. Goldammer. Springer, Berlin, pp. 82-105.

Devoto, M.; Medan, D. and Montaldo, N. H. (2005), Patterns of interaction between plants and pollinators along an environmental gradient. Oikos, 109, 461472.

Dulmen Van, A. (2001), Pollination and phenology of flowers in the canopy of two contrasting rain forest types in Amazonia, Colombia. Plant Ecol., 153, 7385.

Franco, A. L. M. (1995), Ecologia da polinização e biologia reprodutiva de sete espécies de Phaseoleae. $\mathrm{PhD}$ Thesis, State University of Campinas, Campinas, Brazil.

Frankie, G. W. (1975), Tropical forest phenology and pollinator plant coevolution. In - Coevolution of animals and plants, eds. L. E. Gilbert and P. H. Haven. University of Texas Press, Austin.

Freitas, C. V. and Oliveira, P. E. (2002), Biologia reprodutiva de Copaifera langsdorffii Desf. (Leguminosae, Caesalpinioideae). Rev. Brasil. Bot., 25, 311-321.

Gentry, A. H. (1982), Neotropical floristic diversity: phytogeographical connections between Central and South America, Pleistocene climatic fluctuations, or an accident of the Andean Orogeny? Ann. Mo. Bot. Gard., 69, 557-593.

Gibbs, P. E.; Oliveira, P. E. and Bianchi, M. B. (1999), Postzygotic control of selfing in Hymenaea stigonocarpa (Leguminosae-Caesalpinioideae), a batpollinated tree of the Brazilian cerrados. Int. J. Plant Sci., 160, 72-78. 
Goldenberg, R. and Shepherd, G. J. (1998), Studies on the reproductive biology of Melastomataceae in "cerrado" vegetation. Plant Syst. Evol., 211, 13-29.

Gottsberger, G. (1986), Some Pollination Strategies in Neotropical Savannas and Forests. Plant Syst. Evol., 152, 29-45.

Gottsberger, G. (1994), As anonáceas do cerrado e a sua polinização. Rev. Brasil. Biol., 54, 391-402.

Gottsberger, G. (1999), Pollination and evolution in neotropical Annonaceae. Plant Sp. Biol., 14, 143-152.

Heithaus, E. R. (1974), The role of plant-pollinator interactions in determining community structure. Ann. Mo. Bot. Gard., 61, 675-691.

Judd, W. S.; Campbell, C. S.; Kellog, E. A. and Stevens, P. F. (1999), Plant systematics: a phylogenetic approach. Sinauer, Sunderland.

Kaur, A.; Ha, C. D.; Jong, K.; Sands, V. E.; Chan, H. T.; Solpadmo, E. and Ashton, P. S. (1978), Apomixis may be widespread among trees of the climax rain forest. Nature, 271, 440-442.

Köppen, W. (1931), Grundriss der Klimakunde. Gruyter, Berlin.

Kress, W. J. and Beach, J. H. (1994), Flowering plant reproductive systems. In - La Selva. Ecology and natural history of neotropical rain forest, eds. L. A. McDade, K. S. Bawa, H. A. Hespenheide and G. S. Hartshorn. University Chicago, Chicago, pp. 161182.

Morellato, L. P. C. (1991), Estudo da fenologia de árvores, arbustos e lianas de uma floresta semidecídua no Sudoeste do Brasil. PhD Thesis, State University of Campinas, Campinas, Brazil.

Mueller-Dombois, D. and Ellenberg, H. (1974), Aims and methods of vegetation ecology. John Willey and Sons, New York.

Nason, J. D.; Aldrich, P. R. and Hamrick, J. L. (1997), Dispersal and the dynamics of genetic structure in fragmented tropical tree populations. In - Tropical forest remnants: ecology, management, and conservation of fragmented communities, eds. W. F. Laurence and R. O. Bierregard Jr. University of Chicago Press, Chicago, Illinois.

Oliveira, P. E. and Gibbs, P. E. (1994), Pollination biology and breeding systems of six Vochysia species (Vochysiaceae) in Central Brazil. J. Trop. Ecol., 10, 509-522.

Oliveira, P. E. and Gibbs, P. E. (2000), Reproductive biology of woody plants in a cerrado community of Central Brazil. Flora, 195, 311-329.

Oliveira, P. E. and Gibbs, P. E. (2002), Pollination and reproductive biology in cerrado plant communities. In - The cerrados of Brazil: ecology and natural history of a Neotropical savanna, eds. P. E. Oliveira and R. J. Marquis. Columbia University, New York, pp. 329347.
Oliveira, P. E. and Paula, F. R. (2001), Fenologia e biologia reprodutiva de plantas de matas de galeria. In - Cerrado: caracterização e recuperação de matas de galeria, eds. J. F. Ribeiro, C. E. L. da Fonseca and J. C. Souza-Silva. Embrapa, Planaltina, pp. 303-331.

Oliveira, P. E. and Sazima, M. (1990), Pollination biology of two species of Kielmeyera (Guttiferae) from Brazilian cerrado vegetation. Plant Syst. Evol., 172, 35-49.

Oliveira, P. E.; Gibbs, P. E.; Barbosa, A. A. and Talavera, S. (1992), Contrasting breeding systems in two Eriotheca (Bombacaceae) species of the Brazilian cerrados. Plant Syst. Evol., 179, 207-219.

Oliveira, P. E.; Gibbs, P. E. and Barbosa, A. A. (2004), Moth pollination of woody species in the cerrados of central Brazil: a case of so much owed to so few? Plant Syst. Evol., 245, 41-54.

Opler, P. A.; Baker, H. G. and Frankie, G. W. (1980a), Plant reproductive characteristics during secondary succession in Neotropical lowland forest ecosystems. Biotropica, 12 (Supplement), 40-46.

Opler, P. A.; Frankie, G. W. and Baker, H. G. (1980b), Comparative phenology studies of treelet and shrub species in tropical wet and dry forest in the lowland of Costa Rica. J. Ecol., 68, 189-209.

Proença, C. E. B. and Gibbs, P. E. (1994), Reproductive biology of eight sympatric Myrtaceae from Central Brazil. New Phytol., 126, 343-354.

Ramalho, M. (2004), Stingless bees and mass flowering trees in the canopy of Atlantic Forest: a tight relationship. Acta Bot. Brasil., 18, 37-47.

Ramírez, N. (1989), Biologia de polinizacion en una comunidad arbustiva tropical de la alta guayana Venezolana. Biotropica, 21, 319-330.

Ramírez, N. (1993), Reproductive biology in a tropical shrubland of Venezuelan Guayana. J. Veg. Sci., 4, 512.

Ramírez, N. (2004), Ecology of pollination in a tropical Venezuelan savanna. Plant Ecol., 173, 171-189.

Ramos-Neto, M. B. and Pivello, V. R. (2000), Lightning fires in a Brazilian savanna National Park: rethinking management strategies. Environ. Manage., 26, 675-684.

Ratter, J. A.; Ribeiro, J. F. and Bridgewater, S. (1997), The Brazilian cerrado vegetation and threats to its biodiversity. Ann. Bot., 80, 223-230.

Regal, P. J. (1982), Pollination by Wind and animals: Ecology of geographic patterns. Ann. Rev. Ecol. Syst. 13, 497-524.

Roth, I. (1987), Stratification of a tropical forest as seen in dispersal types. Dr W. Junk, Dordrecht.

Saraiva, L. C.; César, O. and Monteiro, R. (1988), Biologia da polinização e sistemas de reprodução de Styrax camporum Pohl e S. ferrugineus Nees et Mart. (Styracaceae). Rev. Brasil. Bot., 11, 71-80. 
Sarmiento, G. (1983), The savannas of tropical America. In - Ecosystems of the world: tropical savannas, ed. D. W. Goodall. Elsevier, Amsterdam, pp. 245-288.

Sazima, M. and Sazima, I. (1975), Quiropterofilia em Lafoensia pacari St. Hil. (Lythraceae), na Serra do Cipó, Minas Gerais. Ciência e Cultura, 27, 405-416.

Sigrist, M. R. (2001), Biologia reprodutiva de doze espécies simpátricas de Malpighiaceae em mata semidecídua do sudoeste Brazileiro. PhD Thesis, State University of Campinas, Campinas, Brazil.

Silberbauer-Gottsberger, I. and Gottsberger, G. (1988), A polinização de plantas do cerrado. Rev. Brasil. Biol., 48, 651-663.

Silberbauer-Gottsberger, I.; Gottsberger, G. and Webber, A. C. (2003), Morphological and functional flower characteristics of New and Old world annonaceae with respect to their mode of pollination. Taxon, 52, 701-718.

Smith, A. P. (1973), Stratification of temperate and tropical forest. Am. Nat., 107, 671-683.

Torezan-Silingardi, H. M. and Del-Claro, K. (1998), Behavior of visitors and reproductive biology of Campomanesia pubescens (Myrtaceae) in cerrado vegetation. Ciência e Cultura, 50, 281-284.
Viana, B. F.; Kleinert, A. M. P. and ImperatrizFonseca, V. L. (1997), Abundance and flower visits of bees in a Cerrado of Bahia, Tropical Brazil. Stud. Neotrop. Fauna and Environment, 32, 212-219.

Waller, D. M. (1988), Plant morphology and reproduction. In - Plant Reproductive EcologyPatterns and Strategies, eds. J. L. Doust and L. L. Doust. Oxford University, New York.

Weber, W. A. (1982), Mnemonic three-letter acronyms for the families of vascular plants: a device for more effective herbarium curation. Taxon, 31, 74-88.

Zar, J. H. (1999), Biostatiscal analysis. Prentice Hall, Upper Saddle River.
Received: May 13, 2005; Revised: March 13, 2006; Accepted: March 14, 2007. 